\title{
RESEARCHPAPER
}

\section{Study of germination percentage, root length and shoot length of Trigonella foenum graecum (Fenugreek) irrigated with river, sewage and coalmine water}

\author{
Pratibha Sharma \\ Department of Biochemistry, Govt. Holkar Science College, Indore (M.P.) India \\ Email: pratibharoma@gmail.com
}

Article Info : Received : 30.12.2019; Revised : 02.03.2020; Accepted : 16.03.2020

Today soil contamination is becoming a serious problem for irrigation purpose therefore the present work was done to know the impact of water from coalmine and sewage on germination percentage, root and shoot length of Trigonella foenum graecum. River water was used as a control. Germination percentage was insignificantly increased in sewage and coalmine water as compared to control (river). Significant increase was observed in root length in sewage water as compared to control. Shoot length was insignificantly decreased in sewage and coalmine water as compared to control. It can be concluded from the present study that sewage and coalmine water can be used to irrigate crops and using different sources of water for irrigation is a good way to utilize different type of wastes.

Key words : Germination percentage, Root length, Shoot length, River water, Sewage water, Coalmine water

How to cite this paper: Sharma, Pratibha (2020). Study of germination percentage, root length and shoot length of Trigonella foenum graecum (Fenugreek) irrigated with river, sewage and coalmine water. Asian J. Bio. Sci., 15 (1) : 1-5. DOI : 10.15740/HAS/AJBS/15.1/1-5. Copyright@ 2020: Hind Agri-Horticultural Society. 